\title{
PENGEMBANGAN PERENCANAAN PENDIDIKAN ISLAM (Konsep Strategi Pengembangan di Indonesia)
}

Dwi Priyanto

Dosen tetap Sekolah Tinggi Agama Islam Negeri Purwokerto

\begin{abstract}
Planning is a very important and strategic factor of its nature as a guide for the implementation of an activity in order to achieve the desired goals or objectives. Planning process as a series of activities is undertook to prepare a decision on what is expected to occur and what will be done. In the field of Islamic education, planning is one key factor for the effectiveness of the implementation of educational activities, national and local level. But in practice of the Islamic education implementation, educational planning is viewed as complementary factors, so objectives are not achieved maximally. The importance of planning development strategies of Islamic education in Indonesia is due to the implementation of Islamic education in Indonesia still needs to be done a repositioning effort, so that Islamic education can truly achieve its goals.

Keywords: Strategy development and Islamic educational planning.
\end{abstract}

\section{Pendahuluan}

Dalam suatu kegiatan apa pun bentuknya, perencanaan (planning) adalah faktor yang sangat penting dan strategis sifatnya sebagai pemandu arah bagi pelaksanaan suatu kegiatan dalam rangka mencapai tujuan/ sasaran/target yang diinginkan. Perencanaan sebagai suatu rangkaian proses kegiatan, dilakukan untuk menyiapkan keputusan mengenai apa yang diharapkan terjadi dan apa yang akan dilakukan. Pada dasarnya perencanaan memiliki makna yang sangat kompleks. Perencanaan dapat didefinisikan dalam berbagai macam pengertian, tergantung perspektif yang dipakai serta latar belakang yang memengaruhi seseorang dalam mendefinisikannya. Dalam pengertian yang luas, perencanaan dapat dimaknai sebagai suatu proses mempersiapkan kegiatan-kegiatan secara 
sistematis yang akan dilakukan untuk mencapai tujuan tertentu.

Dalam bidang pendidikan Islam, perencanaan merupakan salah satu faktor kunci efektivitas terlaksananya kegiatan pendidikan demi tercapainya tujuan pendidikan yang diharapkan bagi setiap jenjang dan jenis pendidikan pada tingkat nasional maupun lokal. Pentingnya perencanaan yang baik dalam bidang pendidikan Islam adalah oleh karena pendidikan Islam diyakini oleh umat Islam sebagai jalan hidup manusia yang paling baik. Sebagai jalan yang paling baik, pendidikan Islam perlu direncanakan secara baik dan sistematis, sehingga Pendidikan Islam benar-benar dapat menyejahterakan setiap Muslim, baik di dunia maupun di akhirat. Namun dalam praktek pelaksanaan pendidikan Islam, faktor perencanaan pendidikan baru atau masih lebih banyak dijadikan faktor pelengkap, sehingga sering kali tujuan yang telah ditetapkan tidak tercapai secara maksimal. Penyebabnya adalah karena para perencana pendidikan kurang memahami proses dan mekanisme perencanaan dalam konteks yang lebih komprehensif. Selain itu, posisi bidang perencanaan belum merupakan faktor kunci keberadaan suatu lembaga pendidikan, baik pada tingkat makro maupun mikro.

Karena itu, peran perencanaan pendidikan terhadap pencapaian visi, misi, dan tujuan lembaga pendidikan belum dirasakan secara optimal.

\section{Konsep Perencanaan Pendidikan}

Perencanaan adalah proses pemilihan dan penetapan tujuan, stategi, metode, anggaran, dan standar atau tolok ukur keberhasilan sesuatu kegiatan (Hadari Nawawi, 2001:35). Pengertian tersebut menunjukkan bahwa prencanaan merupakan proses atau rangkaian beberapa kegiatan yang saling berhubungan dalam memilih salah satu di antara beberapa alternatif tentang tujuan yang ingin dicapai oleh suatu organisasi. Kemudian memilih strategi dan metode untuk mencapai tujuan tersebut.

Sementara itu, menurut Ritha F. Dalimunthe (2003:1) perencanaan adalah pemilihan dan penetapan kegiatan, selanjutnya apa yang harus dilakukan, kapan, bagaimana dan oleh siapa. Perencanaan adalah suatu proses yang tidak berakhir bila rencana tersebut telah ditetapkan; rencana haruslah diimplementasikan. Setiap saat selama proses implementasi dan pengawasan, rencana-rencana mungkin memerlukan perbaikan agar tetap 
berguna. "Perencanaan kembali" kadang-kadang dapat menjadi faktor kunci agar mampu menyesuaikan diri dengan situasi dan kondisi baru secepat mungkin.

Conyers \& Hills (1994:36) mendefinisikan "perencanaan" sebagai "suatu proses yang bersinambungan", yang mencakup "keputusankeputusan atau pilihan-pilihan berbagai aiternatif penggunaan sumber daya untuk mencapai tujuan-tujuan tertentu pada masa yang akan datang.“ Dari pengertian-pengertian tersebut, maka perencanaan pendidikan dimaksudkan untuk mempersiapkan semua komponen pendidikan, agar dapat terlaksana proses belajar mengajar yang baik dalam penyelenggaraan pendidikan dalam mencapai sasaran keluaran pendidikan seperti yang diharapkan. Pengorganisasian pendidikan ditujukan untuk menghimpun semua potensi komponen pendidikan dalam suatu organisasi yang sinergis untuk dapat menyelenggarakan pendidikan dengan sebaik-baiknya.

Kegiatan pendidikan adalah pelaksanaan dari penyelenggaraan pendidikan yang telah direncanakan dan diselenggarakan oleh organisasi penyelenggara pendidikan dengan memparhatikan rambu-rambu yang telah ditetapkan dalam perencanaan dalam rangka mencapai hasil keluaran pendidikan yang optimal. Pengendalian pendidikan dimaksudkan untuk menjaga agar penyelenggaraan pendidikan dilaksanakan sesuai yang direncanakan dan semua komponen pendidikan digerakkan secara sinergis dalam proses yang mengarah kepada pencapaian tujuan pendidikan yang dijabarkan dalam sasaran-sasaran menghasilkan keluaran secara optimal seperti yang telah ditetapkan dalam perencanaan pendidikan.

Menurut John R. Kelly (1993:12) perencanaan pendidikan tersebut mengedepankan 4 unsur dasar perencanaan, yaitu:

\section{1) Pemilihan}

Merencanakan berarti memilih. Perencanaan merupakan proses memilih di antara berbagai kegiatan yang diinginkan, karena tidak semua yang diinginkan itu dapat dilakukan dan dicapai dalam waktu yang bersamaan. Hal itu menyiratkan bahwa hubungan antara perencanaan dan proses pengambilan keputusan sangat erat. Oleh karena itu, banyak buku mengenai perencanaan membahas pendekatan-pendekatan alternatif dalam proses pengambilan keputusan, terutama yang berkaitan 
dengan faktor-faktor yang mempengaruhi pengambilan keputusan dan urutan tindakan di dalam proses pengambilan keputusan;

2) Sumber daya

Perencanaan merupakan alat pengalokasian sumber daya. Penggunaan istilah sumber daya di sini menunjukkan segala sesuatu yang dianggap berguna dalam pencapaian suatu tujuan tertentu. Sumber daya di sini mencakup sumber daya manusia; sumber daya alam, sumber daya modal dan keuangan. Perencanaan mencakup proses pengambilan keputusan tentang bagaimana sumber daya yang tersedia itu digunakan sebaik-baiknya. Oleh karena itu, kuantitas dan kualitas sumber daya tersebut sangat berpengaruh dalam proses memilih di antara berbagai pilihan tin-dakan yang ada;

3) Tujuan

Perencanaan merupakan alat untuk mencapai tujuan. Konsep perencanaan sebagai alat pencapaian tujuan muncul berkenaan dengan sifat dan proses penetapan tujuan. Salah satu masalah yang sering dihadapi oleh seorang perencana adalah bahwa tujuan-tujuan mereka kurang dapat dirumuskan secara tepat. Sering kali tujuan-tujuan tersebut didefinisikan secara kurang tegas, karena kadang kala tujuan-tujuan tersebut ditetapkan oleh pihak lain.; dan

4) Waktu

Perencanaan mengacu ke masa depan. Salah satu unsur penting dalam perencanaan adalah unsur waktu. Tujuan-tujuan perencanaan dirancang untuk dicapai pada masa yang akan datang. Oleh karena itu, perencanaan berkaitan dengan masa depan.

\section{Strategi Pengembangan Perencanaan Pendidikan Islam di Indonesia}

Pentingnya strategi pengembangan perencanaan pendidikan Islam di Indonesia, adalah oleh karena dalam penyelenggaraan pendidikan Islam di Indonesia masih perlu dilakukan adanya upaya reposisi, sehingga pendidikan Islam dapat benar-benar mencapai tujuannya.

Upaya-upaya yang dapat dilakukan untuk melakukan reposisi perencanaan Pendidikan Islam di Indonesia dapat berupa hal-hal sebagai berikut; pertama, mengembangkan kesadaran tentang pentingnya Perencanaan Pendidikan Islam. Kedua, mengembangkan sikap menghargai 
profesi perencana di bidang pendidikan. Ketiga, mengembangkan sistem Perencanaan Pendidikan Islam yang baik dan sistematis. Keempat, memperbaiki kualitas dan keakuratan data kependidikan Islam. Kelima, menetapkan model dan metode Perencanaan Pendidikan Islam yang paling sesuai dengan karakteristik dan tujuan Pendidikan Islam. Keenam, mengembangkan manajemen sistem informasi Pendidikan Islam. Ketujuh, mengembangkan sistem perencanaan berbasis penelitian. Adapun penjelasan tentang upaya-upaya di atas sebagai berikut:

1) Mengembangkan Kesadaran Pentingnya Perencanaan Pendidikan Islam.

Mengembangkan kesadaran tentang pentingnya Perencanaan Pendidikan di kalangan para pengambil kebijakan Pendidikan Islam di Indonesia amatlah penting. Pengembangan kesadaran itu sangat perlu dan mendesak, mengingat selama ini, para pengambil kebijakan di bidang Pendidikan Islam masih kelihatan kurang memperhatikan arti penting bidang perencanaan Pendidikan Islam. Sehingga, kalau pun secara formal perencanaan dilakukan, tetapi rumusan strategi, substansi, dan program-programnya hanya dibuat seadanya dan sekenanya. Akibatnya, arah dan tujuan Pendidikan Islam menjadi tidak jelas dan kabur.

2) Mengembangkan Sikap Menghargai Profesi Perencana di Bidang Pendidikan

Profesi perencana di lingkungan Pendidikan Islam, mulai dari tingkat pusat hingga institusi mikro pendidikan (Madrasah, PTAI, dll), masih dipandang sebagaiprofesi yang tidak strategis dan tidakpenting. Padahal, kebijakan pendidikan, termasuk kebijakan Pendidikan Islam, tanpa didukung oleh perencana-perencana yang mumpuni, tentunya tidak akan berjalan secara optimal. Tanpa penghargaan yang proporsional terhadap profesi perencana, maka setiap orang akan berpandangan bahwa jabatan di institusi perencanaan akan dipandang sebagai jabatan "buangan". Bila profesi perencana di bidang Pendidikan Islam dihargai secara proporsional, maka akan berdampak pada peningkatan mutu dan profesionalisme para perencana di bidang Pendidikan Islam, yang pada akhirnya akan meningkatkan mutu dan kehandalan Perencanaan Pendidikan Islam. 
3) Mengembangkan Sistem Perencanaan Pendidikan Islam yang Baik dan Sistemtis

Sistem Perencanaan Pendidikan Islam yang baik dan sistematis adalah prasyarat mutlak untuk mengembangkan masa depan Pendidikan Islam. Strategi untuk mengembangkan sistem perencanaan yang baik dan sistematis dapat dimulai dengan melakukan analisis yang dikenal dengan konsep analisis SWOT. Analisis ini mengharuskan adanya kejujuran dan data yang valid tentang strengths (kekuatan) dan weaknesses (kelemahan), opportunities (peluang/kesempatan) dan threats (ancaman). Pengenalan potensi dan posis diri melalui analisis SWOT tadi adalah suatu prasyarat sebelum Perencanaan Pendidikan Islam dilakukan (Marks \& Spencer, 2007).

Setelah analisis SWOT dilakukan Perencanaan Pendidikan Islam dilanjutkan dengan mengembangkan beberapa kriteria Perencanaan Pendidikan Islam agar dokumen perencanaannya betul-betul dapat menjadi panduan dan pedoman pengembangan Pendidikan Islam di masa kini dan masa mendatang. Data yang akurat dan berkualitas yang diperoleh melalui analisis SWOT tadi menjadi salah satu prasyarat perencanaan pendidikan, termasuk Perencanaan Pendidikan Islam. Tanpa data yang akurat, maka kegiatan perencanaan hanya akan menghasilkan "dokumen sampah" yang tidak bermanfaat, sekaligus dapat membahayakan masa depan kebijakan Pendidikan Islam.

Selama ini harus diakui bahwa data-data yang mendukung kegiatan penyelenggaraan Pendidikan Islam di Indonesia akurasinya masih banyak yang diragukan. Pada akhirnya, berbekal data-data yang kurang akurat tadi kegiatan Pendidikan Islam direncanakan, dan berbagai kebijakan Pendidikan Islam ditetapkan. Akibatnya, dokumen perencanaan di lingkungan Pendidikan Islam seringkali tidak digunakan sebagai panduan dan pedoman, baik dalam menyusun kebijakan maupun dalam kegiatan operasionalnya.

4) Menetapkan Model dan Metode Perencanaan Pendidikan Islam Model dan Metode yang dapat digunakan dalam sistem Perencanaan Pendidikan memang banyak, tetapi para perencana di bidang Pendidikan Islam perlu memilih suatu model dan metode yang dipandang paling baik dan sesuai dengan lingkungan pendidikan Islam. Sebagaimana 
diketahui, selama ini dikenal beberapa model perencanaan, di antaranya (Udin Syaefudin \& Abin Syamsuddin, 2005 : 67):

- Model Perencanaan Komperehensif. Model ini terutama digunakan untuk menganalisis perubahan-perubahan dalam sistem pendidikan secara keseluruhan. Di samping itu berfungsi sebagai suatu patokan dalam menjabarkan rencana-rencana yang lebih spesifik ke arah tujuan-tujuan yang lebih luas.

- Model Target Setting. Model ini diperlukan dalam upaya melaksanakan proyeksi ataupun memperkirakan tingkat perkembangan dalam kurun waktu tertentu.

- Model costing dan keefektifan biaya. Model ini sering digunakan untuk menganalisis proyek-proyek dalam kriteria efisien, efektifitas dan ekonomis. Dengan model ini dapat diketahui proyek yang paling fleksibel dan memberikan suatu perbandingan yang paling baik di antara proyek-proyek yang menjadi alternatif penanggulangan masalah yang dihadapi. Penggunaan model ini dalam pendidikan didasarkan pada pertimbangan bahwa pendidikan itu tidak terlepas dari masalah pembiayaan. Dan, dengan sejumlah biaya yang dikeluarkan selama proses pendidikan, diharapkan dalam kurun waktu tertentu dapat memberikan benefit tertentu.

- Model PPBS. Model PPBS (planning, programming, budgeting system) bermakna bahwa perencanaan, penyusunan program dan penganggaran dipandang sebagai suatu sistem yang tak terpisahkan satu sama lainnya. PPBS merupakan suatu proses yang komprehensif untuk pengambilan keputusan yang lebih efektif. Dalam istilah lain, model PPBS merupakan suatu pendekatan yang sistematik yang berusaha untuk menetapkan tujuan, mengembangkan programprogram, menentukan besarnya biaya, dan proses penganggaran yang merefleksikan kegiatan program jangka panjang.

Untuk memahami PPBS secara lebih baik, maka perlu diperhatikan sifat-sifat esensial dari sistem ini, yakni: (1) memerinci secara cermat dan menganalisis secara sistematik terhadap tujuan yang hendak dicapai; (2) mencari alternatif-alternatif yang relevan, serta cara yang berbeda-beda untuk mencapai tujuan; (3) menggambarkan biaya total 
dari setiap alternatif, baik langsung atau pun tidak langsung, biaya yang telah lewat atau pun biaya yang akan datang, baik biaya yang berupa uang maupun biaya yang tidak berupa uang; (4) memberikan gambaran tentang efektifitas setiap alternatif dan bagaimana alternatif itu mencapai tujuan; dan (5) membandingkan dan menganalisis alternatif tersebut, yaitu mencari kombinasi yang memberikan efektivitas yang paling besar dari sumber yang ada dalam pencapaian tujuan(Udin Syaefudin \& Abin Syamsuddin, 2005 : 69).

5) Mengembangkan Manajemen Sistem Informasi Pendidikan Islam Dalam konteks perencanaan Pendidikan Islam, kedudukan manajemen sistem informasi pendidikan amatlah penting. Manajemen Sistem Informasi Pendidikan ini setidaknya harus mencakup pengelolaan informasi tentang siswa, karyawan, bangunan, program, dan finansial (Wahyudi, $2002: 281$ ).

- Manajamen sistem informasi pendidikan yang berkenaan dengan siswa pada lingkungan lembaga Pendidikan Islam dapat berupa: a) menyediakan informasi tentang tingkat, jumlah, skor, tes kesehatan, kehadiran, dan faktor-faktor kesiswaan lainnya, b) menyediakan informasi tentang pengalaman siswa di luar lembaga pendidikan yang mempunyai pengaruh signifikan dalam proses pembelajaran, c) memberikan informasi perbandingan prestasi siswa dengan siswa lain di komunitasnya serta dalam lingkungan wilayah lembaga pendidikan, d) memberikan informasi kurikuler, ekstrakurikuler, dan program-program pengayaan yang didukung oleh masyarakat, e) memberikan informasi tentang sejumlah identifikasi yang memungkinkan siswa dapat mengikuti jenjang karir jika ia pindah dari lembaga pendidikan ke suatu lembaga pendidikan yang lain.

- Manajamen sistem informasi pendidikan yang berkenaan dengan karyawan dapat berupa: a) menyediakan informasi tentang kemampuan dan preferensi guru, serta dalam mempersipkan proses pembelajaran, b) menyediakan informasi tentang tugas dan alokasi jadwal guru, c) menyediakan informasi tentang fungsi-fungsi yang sesungguhnya yang berkenaan dengan performansi guru, d) menyediakan informasi tentang efektivitas pembelajaran yang dapat dilakukan oleh para guru, dan e) memberikan informasi tentang 
prakiraan kebutuhan untuk menunjang keterampilan mengajar.

- Manajamen sistem informasi pendidikan yang berkenaan dengan bangunan dapat berupa: a) menyediakan informasi tentang lokasi, jenis, ukuran, kapasitas, sistem struktur, biaya pemeliharaan dan lain sebagainya, b) menyediakan informasi tentang perlengkapan lembaga pendidikan, lokasi, usia, biaya, dan pemanfaatannya, dan c) menyediakan informasi tentang kualitas lingkungan lembaga pendidikan, dukungan komunitas dan lain sebagainya.

- Manajamen sistem informasi pendidikan yang berkenaan dengan program dapat berupa: a) memberikan informasi tentang apa yang dikerjakan oleh peserta didik, bagaimana mengerjakannya, oleh sispa, berapa banyak biaya yang diperlukan dan lain-lain, b) menyediakan informasi tentang kurikulum yang ada, proses pembelajaran dan prosedur evaluasi, c) memberikan informasi tentang hasil dari pencapaian kurikulum yang diajarkan, d) memberikan informasi tentang perbandingan dan efektifitas berbagai proyek yang dilaksanakan, e) semua sistem informasi pendidikan tersebut direncanakan dalam suatu perencanaan pendidikan. Bahan-bahan yang disajikan dalam manajemen sistem informasi pendidikan itu diperoleh dari suatu hasil penelitian yang akurat yang didukung oleh data-data kuantitatif maupun kualitatif.

6) Mengembangkan Sistem Perencanaan Berbasis Penelitian

Untuk mengembangkan sistem perencanaan Pendidikan Islam yang efektif, maka sistem Perencanaan Pendidikan Islam mesti didasarkan pada hasil penelitian. Dengan perencanaan berbasis penelitian, maka Perencanaan Pendidikan Islam akan memiliki landasan data yang memiliki validitas dan reliabilitas yang baik, sehingga proses Perencanaan Pendidikan Islam tidak hanya didasarkan pada asumsiasumsi dan perkiraan-perkiraan tanpa data yang akurat. Pentingnya penelitian sebagai basis Perencanaan Pendidikan Islam, adalah karena dengan penelitian, maka akan dihasilkan data-data empirik yang valid, akurat, dan tidak didasarkan pada dugaan-dugaan.

Oleh karena itu. perlu ada political will dari para pengambil kebijakan bidang pendidikan Islam, sehingga perencanaan dapat diaplikasikan 


\section{Dwi Priyanto}

sesuai dengan teori-teori perencanaan pendidikan yang diakui secara luas di dunia pendidikan. Dalam hal ini upaya yang perlu dilakukan adalah dengan mengembangkan sistem perencanaan Pendidikan Islam dalam arti yang sesungguhnya. Perencanaan Pendidikan Islam dalam arti yang sesungguhnya berarti memandang perencanaan sebagai proses pemilihan dan penetapan tujuan, stategi, metode, anggaran, dan standar (tolak ukur) keberhasilan sesuatu kegiatan (Hadari Nawawi, 2001 : 35).

Hal itu berarti bahwa prencanaan merupakan proses atau rangkaian beberapa kegiatan yang saling berhubungan dalam memilih salah satu di antara beberapa alternatif tentang tujuan yang ingin dicpai oleh suatu organisasi. Kemusian memilih strategi dan metode untuk mencapai tujuan tersebut.

Perencanaan Pendidikan dalam arti yang sesungguhnya juga bermakna pemilihan dan penetapan kegiatan, selanjutnya apa yang harus dilakukan, kapan, bagaimana dan oleh siapa (Dalimunthe, $2003: 1$ ) atau suatu proses yang tidak berakhir bila rencana tersebut telah ditetapkan; rencana haruslah diimplementasikan. Setiap saat selama proses implementasi dan pengawasan, rencana-rencana mungkin memerlukan perbaikan agar tetap berguna. "Perencanaan kembali" kadang-kadang dapat menjadi faktor kunci agar mampu menyesuaikan diri dengan situasi dan kondisi baru secepat mungkin. Dengan kata lain, perencanaan yang sesungguhnya dan bukan asal-asalan adalah perencanaan sebagai suatu proses yang berkesinambungan, yang mencakup keputusan-keputusan atau pilihan-pilihan berbagai alternatif penggunaan sumber daya untuk mencapai tujuan-tujuan tertentu pada masa yang akan datang(Conyers \& Hills, 1994:36).

Dengan demikian, maka Perencanaan Pendidikan Islam diarahkan untuk mempersiapkan semua komponen pendidikan, agar dapat terlaksana proses belajar mengajar yang baik dalam penyelenggaraan pendidikan serta dalam mencapai sasaran keluaran pendidikan seperti yang diharapkan. Pengorganisasian pendidikan ditujukan untuk menghimpun semua potensi komponen pendidikan dalam suatu organisasi yang sinergis untuk dapat menyelenggarakan pendidikan dengan sebaik-baiknya. 


\section{Penutup}

Dari pemaparan yang talah dilakukan, maka strategi dan mekanisme Perencanaan Pendidikan Islam yang dapat dilakukan dengan menggabungkan pendekatan perencanaan dari bawah ke atas dan dari atas ke bawah. Mekanisme perencanaan dari bawah ke atas biasanya dilakukan karena ingin memenuhi kebutuhan nyata masyarakat terhadap pendidikan. Perencanaan dari bawah ke atas ini dimulai prosesnya dengan mengenali kebutuhan di tingkat masyarakat yang secara langsung yang terkait dengan pelaksanaan dan mendapat dampak dari kegiatan pendidikan yang direncanakan.

Sementara itu, perencanaan dari atas ke bawah adalah pendekatan perencanaan yang menerapkan cara penjabaran rencana induk ke dalam rencana rinci. Rencana rinci yang berada di "bawah" adalah penjabaran rencana induk yang berada di "atas". Pendekatan perencanaan sektoral acapkali ditunjuk sebagai pendekatan perencanaan dari atas ke bawah, karena target yang ditentukan secara nasional dijabarkan ke dalam rencana kegiatan di berbagai daerah di seluruh Indonesia yang mengacu kepada pencapaian target nasional tersebut. Pendekatan perencanaan dari atas ke bawah ini lebih dominan pada masa awal-awal pembangunan, terutama karena masih serba terbatasnya sumber daya pembangunan yang tersedia. Namun, mekanisme perencanaan dari atas ke bawah tersebut tidak lagi sepenuhnya dijalankan karena proses perencanaan yang rinci menuntut peran serta masyarakat.

Oleh karena itu, mekanisme yang dipandang paling sesuai dengan Perencanaan Pendidikan Islam adalah memadukan pendekatan perencanaan dari atas ke bawah dengan perencanaan dari bawah ke atas. Secara operasional pendekatan perencanaan gabungan antara "dari bawah ke atas" dengan "dari atas ke bawah" ditempuh melalui mekanisme yang memanfaatkan:

- Forum Komite Madrasah atau Asosiasi Guru di tingkat institusi pendidikan,

- Forum Komite Madrasah atau Asosiasi Guru pada tingkat Kecamatan,

- Forum Dewan Pendidikan atau Forum Guru (PGRI) pada tingkat Kabupaten/Kota,

- Forum-forum Kepala Madrasah pada berbagai tingkatan, 
- Rapat-rapat Koordinasi Pendidikan Islam pada berbagai tingkatan, dan

- Kebijakan pada tingkat Nasional.

Pada setiap tingkat diupayakan untuk mengadakan koordinasi perencanaan institusional, regional, dan akhirnya nasional. Usulan atau masalah yang lintas wilayah atau lintas sektoral yang tidak dapat diselesaikan di suatu tingkat dibawa ke tingkat di atasnya. Proses berjenjang ini diharapkan dapat mempertajam analisis di berbagai tingkat forum konsultasi Perencanaan Pendidikan Nasional.

Dengan demikian, perencanaan dari "atas ke bawah" yang memberikan gambaran tentang perkiraan-perkiraan dan kemungkinankemungkinan yang ada, diinformasikan secara berjenjang, sehingga proses perencanaan dari "bawah ke atas" (bottom-up planning) diharapkan sejalan dengan yang ditunjukkan dari "atas ke bawah" (top-down planning).

\section{DAFTAR PUSTAKA}

Conyers \& Hills. 1994. Creative Human Resource Planning and Applications : A Strategic Approach. New York Prectice Hall, Inc.

Dalimunthe, Ritha F. 2003. Keterkaitan antara Penelitian Manajemen dengan Pendidikan dan Pengembangan Ilmu Manajemen. Medan: Universitas Sumatra Utara.

Gibson, Ivansevic \& Donelly. 2001. Organizations: Behavior, Structure, Proceses. USA: Mc Graw Hill.

John N. Gardner \& Jewler A. Jerome (Ed.). 1998. College is Only the Beginning: A Student Guide to Higher Education. New York: Wardsworth Publishing Company.

John R. Kelly. 1993. Leisure. Englewood Cliffs, NJ: Prentice-Hall, Inc.

Johnson, Allan G. 1985. Human Arangements: An Introduction to Sociology. Orlando-Florida: Harcourt Brace Jovanovich, Inc.

Kathy Daly, Sweet Success. 2007. Herff Jones Company of Indiana, Inc. (http://www.yearbooks.biz/nav1024.cfm?cat=5\&subcat=26\&sub sub=3\&method=display\&id=481), diakses tanggal 17 September 2011. 
Marks \& Spencer Pulbication. 2007, SWOT Analysis; Strategies and Implementation.

(http://www.universitip.com/term-papers/SWOT-Analysis-Strategiesand-Implementation-f-Marks-Spencer-898598870.html), diakses tanggal 13 September 2011.

Nawawi, H. Hadari. 2001. Perencanaan SDM untuk Organiasi Profit. Yogyakarta: Gadjah Mada University.

Sa'ud, Udin Syaefudin dan Abin Syamsuddin Makmun. 2005. Perencanaan Pendidikan: Suatu Pendekatan Komprehensif. Bandung: Remaja Rosdakarya.

Wahyudi. 2002. Sistem Informasi Manajemen dalam OrganisasiOrganisasi Publik. Yogyakarta: Gadjah Mada Press. 